\title{
Do the Amount of Fluid, Histopathology, Radiology and Pleurodesis Status Affect the Survival in Malignant Pleural Effusions?
}

\author{
Malign Plevral Effüzyonlarda Sıvı Miktarı, Histopatoloji, \\ Radyoloji ve Plöredez Durumu Sağkalımı Etkiliyor mu?
}

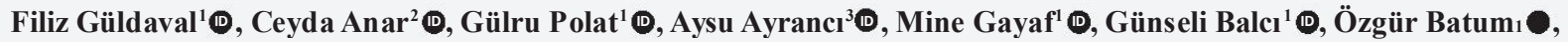 \\ Gülistan Karadeniz ${ }^{1} \mathbb{D}$, Fatma Üçsular ${ }^{1} \mathbb{D}$, Bilge Salık ${ }^{1} \mathbb{D}$, Emel Tellioğlü ${ }^{1}$, Berna Komurcuoglu ${ }^{1} \mathbb{D}$, Dursun Tatar $^{1} \mathbb{D}$, Seher Susam ${ }^{4}$, \\ Yasemin Özdoğan ${ }^{1}$ (D, Nimet Aksel ${ }^{1}$ (), Melih Büyükşirinn ${ }^{1}$ (D)
}

\begin{abstract}
'Department of Pulmonology, Health Science University Doctor Suat Seren Chest Diseases and Surgery Training and Research Hospital, Izmir, Turkey ${ }^{2}$ Department of Pulmonology, İzmir Katip Çelebi University, Atatürk Training and Research Hospital, Izmir, Turkey

${ }^{3}$ Department of Pulmonology, İzmir Bakırçay University, Çiğli Training and Research Hospital, Izmir, Turkey

${ }^{4}$ Deparment of Radiology, Health Science University Doctor Suat Seren Chest Diseases and Surgery Training and Research Hospital, Izmir, Turkey
\end{abstract}

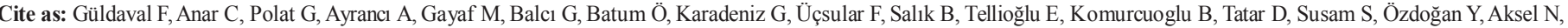
Büyükşirin M. Do the amount of fluid, histopathology, radiology and pleurodesis status affect the survival in malignant pleural effusions?. Kocaeli Med J 2021;10(2):39-44.

\section{Abstract}

INTRODUCTION: The primary objective of this study was to identify the most common pleural malignancies leading to malign pleural effusion (MPE). The secondary objective was to evaluate the relationship between the amount of fluid and radiological findings, etiologies, treatment methods and survival.

METHODS: We retrospectively included cases of MPE with a tissue diagnosis.

RESULTS: The most common causes of MPE were lung cancer $(73 \%)$, breast cancer $(8.3 \%)$ and mesothelioma $(7 \%)$. In patients who were offered chemical pleurodesis, pleurodesis was successful in nearly $31.1 \%$. No relation was found between the amount of pleural fluid and cell type, survival, pulmonary, extrapulmonary malignancy and mesothelioma, Patients live longer if pleurodesis was successful $(\mathrm{p}=$ 0.005 ). Median survival of patients with MPE due to pulmonary, extrapulmonary and mesothelioma, respectively were $77 \pm 12.8,150 \pm 48.4$ and $365 \pm 0$ days. The survival of the patients with mesothelioma was significantly longer than others (P: 0.000$)$.

DISCUSSION AND CONCLUSION: The main cause of MPE was lung cancer, followed by breast cancer, unknown primary and mesothelioma. Chemical pleurodesis was a viable palliative measure for MPE. Successful pleurodesis had a significant contribution to the survival.

Keywords: malignant pleural effusions, survival, treatment

$\ddot{\mathrm{O} z}$

GíRiş ve AMAÇ: Bu çalışmanın birincil amacı, malign plevral efüzyona (MPE) yol açan en yaygın plevral maligniteleri belirlemektir. İkincil amaç, sıvı miktarı ile radyolojik bulgular, etiyolojiler, tedavi yöntemleri ve sağkalım arasındaki ilişkiyi değerlendirmektir.

YÖNTEM ve GEREÇLER: Çalışmamıza retrospektif olarak doku tanısı almış MPE vakalarını dahil ettik.

BULGULAR: MPE'nin en yaygin nedenleri akciğer kanseri ( $\% 73)$, meme kanseri ( $\%$ 8.3) ve mezotelyoma (\% 7) idi. Kimyasal plöredez önerilen hastalarda plöredez yaklaşık\% 31.1 oranında başarılı olmuştur. Plevral sıvı miktarı ile hücre tipi, sağkalım, pulmoner, ekstrapulmoner malignite ve mezotelyoma arasında ilişki bulunmadı, hastalar plöredez başarılı ise daha uzun sağkalıma sahipti (p $=0.005)$. Pulmoner, ekstrapulmoner ve mezotelyoma nedeniyle MPE'li hastaların medyan sağkalımı sırasıyla $77 \pm 12.8,150 \pm 48.4$ ve $365 \pm 0$ gündü. Mezotelyomalı hastaların sağkalımı diğerlerine göre anlamlı olarak daha uzundu (P: 0.000$)$

TARTIŞMA ve SONUÇ: MPE'nin ana nedeni akciğer kanseriydi, ardından meme kanseri, primer bilinmeyen maligniteler ve mezotelyoma geldi. Kimyasal plöredez, MPE için geçerli bir palyatif önlemdi. Başarılı plöredezin sağkalıma önemli bir katkısı vardı.

Anahtar Kelimeler: malign plevral efüzyon, sağkalım, tedavi
Gelis tarihi / Received: 19.02.2021

Kabul tarihi / Accepted: 29.06.2021

$$
\begin{array}{r}
\text { Sorumlu Yazar/Corresponding Author: } \\
\text { Aysu Ayranc1 } \\
\text { Department of Pulmonology, İzmir } \\
\text { Bakırçay University, Çiğli Training and } \\
\text { Research Hospital, Izmir, Turkey } \\
\text { draysu87@gmail.com } \\
\text { ORCID: 0000-0002-8939-336X }
\end{array}
$$

F. Güldaval 0000-0002-7712-5093 C. Anar 0000-0002-3922-5800

G. Polat 0000-0002-2211-1268

M. Gayaf 0000-0003-1375-6221

G. Balc1 0000-0002-4160-085X

Ö. Batum 0000-0002-8353-3421

G. Karadeniz 0000-0002-1994-6723

F. Üçsular 0000-0003-3746-3095

B. Salık 0000-0002-8999-0287

E. Tellioğlu 0000-0001-6890-6413

B. Komurcuoglu 0000-0002-2877-242X

D. Tatar 0000-0002-6285-3549

S. Susam 0000-0003-2021-4594

Y. Özdoğan 0000-0003-2693-9756

N. Aksel 0000-0001-8725-3323

M. Büyükşirin 0000-0003-0700-2546 


\section{INTRODUCTION}

Malignant pleural effusion (MPE) is the most frequently detected reason for exudative pleural fluids. Pleural involvement is seen in $30-50 \%$ of metastatic malignancies, the amount of pleural fluid varies from non-massive to massive $(1,2)$. MPEs may make malignancies become complicated, despite the fact that lung / breast cancers are the most common reason in this respect (1). It was argued by previous authors that haematogenous spread of malignant cells to visceral pleura with secondary seeding to parietal pleura cause MPE (3). The course of primary disease in the presence of MPE also has a poor prognosis (1). The average survival varies between 3 and 12 months. In addition to the treatment of primary disease, there are treatment alternatives such as tube thoracostomy, pleurodesis and permanent pleural catheter (1).

The present study basically aimed to determine the most prevalent pleural malignancies causing MPE in a large tertiary hospital in Izmir, Turkey. The secondary objective was to evaluate the relationship between the radiological appearance and etiology, treatment methods and survival.

\section{MATERIALS AND METHOD}

\section{Study design and population}

The files of patients with MPE who were diagnosed with pleural fluid cytology or pleural biopsy between 2013 and 2018 were analyzed retrospectively. The fluid amount and pleural involvement images were evaluated from thoracic computed tomography (CT) and chest radiographs. Primary malignancy was divided into three groups; pulmonary, extrapulmonary malignancies and mesothelioma. Histological subtypes of lung cancers were determined. Treatment methods and the survival of the patients were recorded. Pleurodesis was performed in patients with shortness of breath, massive fluid and no endobronchial lesions. Pleurodesis was performed with talc in all patients. Pleurodesis was not performed in patients with loculated pleural fluid. No complications developed in patients who underwent pleurodesis.

\section{Imaging}

The sizes of pleural effusion were categorized into three classifications on the chest radiograph: mild (less than one-third of hemithorax), moderate (one-third - two-thirds of hemithorax), and massive (more than two-thirds of hemithorax). CT scans were evaluated in terms of pleural thickening $(\geq 10 \mathrm{~mm})$ and nodularity of visceral and parietal layers.

\section{Ethics Approval}

Ethical approval was obtained from Local Ethics Committee with the number 49109414-604.02 dated 22.04.2019.

\section{Statistical Analysis}

Continuous variables were indicated as median (25-75\%), categorical variables as numbers. Comparisons were made using the Man Whitney or Chi-square test. Survival analysis was done with the Kaplan Meier and multivariate regression analysis was used for factors affecting survival.

\section{RESULTS}

A total of 533 patients (median age 64 years, 336 males) were included in the study. While 504 (95\%) of the patients were diagnosed with pleural fluid cytology, 29 (5\%) of them were diagnosed with video assisted thoracic surgery (VATS). While primary malignancy was lung cancer in 389 (73\%) of the cases, non-pulmonary malignancy was detected in $108(20 \%)$ and malignant mesothelioma in $36(7 \%)$ cases. The distribution of lung cancer by histological types are $289(54.2 \%)$ adenocarcinoma, 18 (3.4\%) squamous cell carcinoma, 78 (14.6\%) small cell lung carcinoma, $1(0.2 \%)$ large cell lung carcinoma, and 10 (1.9\%) were not otherwise specified (NOS). Among the extrapulmonary malignancies, the most common was breast cancer at $44(8.3 \%)$, while the genitourinary system was seen in $28(5.3 \%)$, a gastrointestinal system in $22(4.1 \%)$, lymphoma in $5(0.9 \%)$ and other malignancies were observed in $10(1.9 \%)$ cases. The major underlying diagnoses are given in Table 1.

Table 1. Patient characteristics, diagnostic methods and pleural fluid diagnoses

\begin{tabular}{ll}
\hline Age (Median) & 64 \\
\hline Gender ( N,\%) & $336(63 \%)$ \\
Male & $197(37 \%)$ \\
Female & \\
Diagnostic method ( N,\%) & $504(94.6 \%)$ \\
Cytology & $25(4.7 \%)$ \\
Surgery & $389(73 \%)$ \\
Pulmonary ( N,\%) & $108(20 \%)$ \\
Extrapulmonary ( N,\%) & $36(7 \%)$ \\
Mesothelioma ( N,\%) & \\
Pulmonary ( N,\%) & $289(54.2 \%)$ \\
Adenocarcinoma & $78(3.4 \%)$ \\
Squamous Cell Carcinoma & $78(14.6 \%)$ \\
Small cell Carcinoma & $1(0.2 \%)$ \\
Large Cell Carcinoma & $10(1.9 \%)$ \\
NOS & \\
Extrapulmonary carcinoma (N,\%) & \\
Breast & $44(8.3 \%)$ \\
Genitourinary system & $28(5.3 \%)$ \\
Gastrointestinal system & $22(4.1 \%)$ \\
Lymphoma & $5(0.9 \%)$ \\
Other & $10(1.9 \%)$ \\
Dead ( N,\%) & $369(69.2 \%)$ \\
Alive ( N,\%) & $164(30.8 \%)$ \\
\hline
\end{tabular}


When looking at the radiological view, pleural thickening was observed in $140(26.3 \%)$ cases, nodulation in $71(13.3 \%)$ cases, and loculated fluid in $13(2.4 \%)$ cases. Pleurodesis was applied to 255 (47.8\%) cases (Table 2).

No relation was found between the amount of pleural fluid and cell type, survival, pulmonary, extrapulmonary malignancy and mesothelioma (Table 3). There was no difference between the amount of pleural fluid and survival (Figure 1).

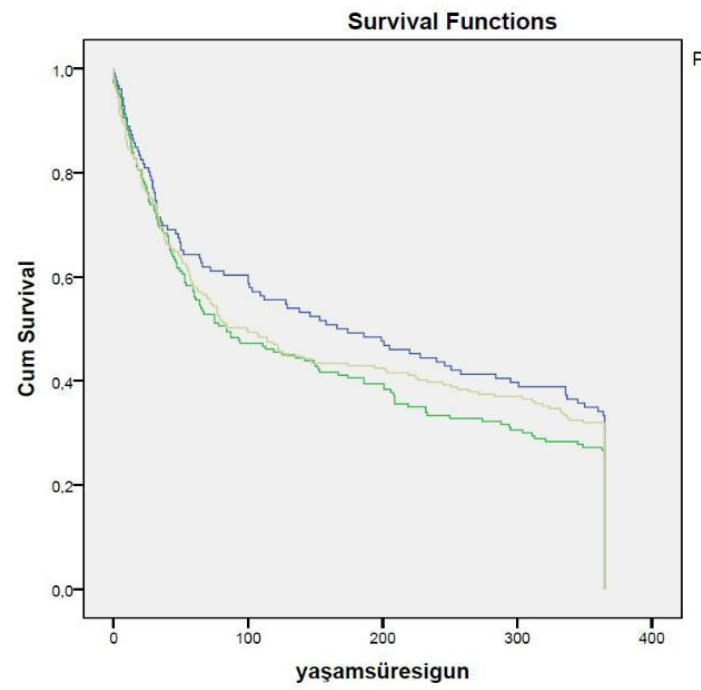

Figure 1. Survival according to the amount of pleural fluid

Pleural nodularity was significantly higher in patients with mesothelioma. Patients were found to live longer if pleurodesis was successful (HR: 1.79 CI: 1.19-2.69, $\mathrm{p}=0.005$ ) (Table 4). However, there was no relation between primary malignancy or the amount of pleural fluid and the success of pleurodesis.

Median survival of patients with malign pleural effusion due to pulmonary, extrapulmonary and mesothelioma was respectively, $77 \pm 12.8,150 \pm 48.4$ and $365 \pm 0$ days. The survival of the patients with mesothelioma was significantly longer than those with pulmonary and extrapulmonary (Figure 2).

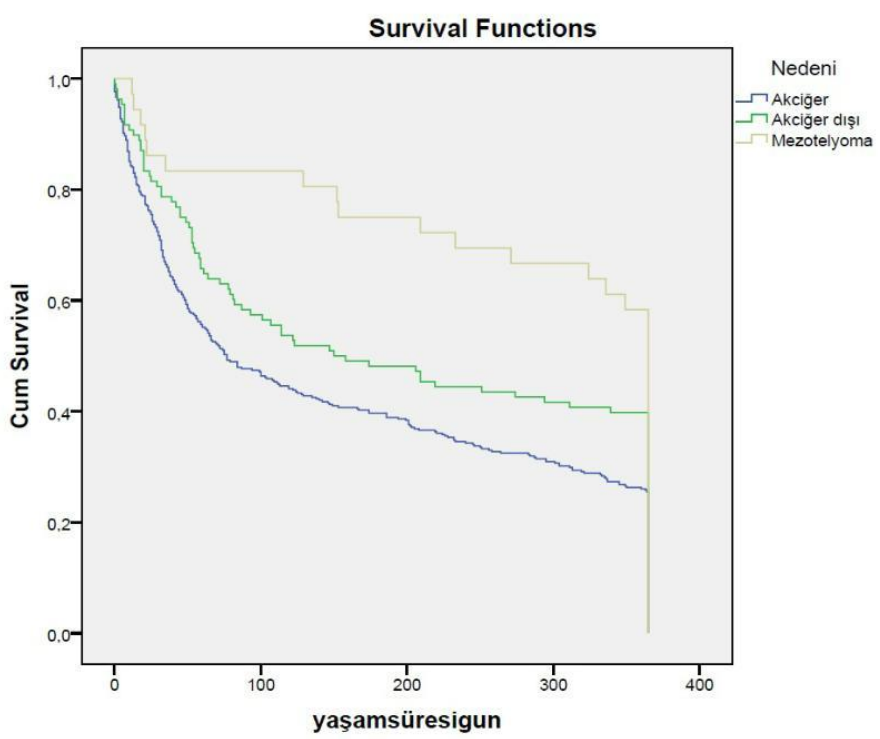

Figure 2. Survival in malignant pleural fluids due to lung, extrapulmonary and mesothelioma
Table 2. Radiological features and pleurodesis method of malignant pleural fluid

\begin{tabular}{|c|c|c|}
\hline & $\mathrm{N}$ & $\%$ \\
\hline $\begin{array}{l}\text { Pleural thickening } \\
\text { Present } \\
\text { Abcent }\end{array}$ & $\begin{array}{l}140 \\
393\end{array}$ & $\begin{array}{l}26.3 \\
73.7\end{array}$ \\
\hline $\begin{array}{l}\text { Nodulation } \\
\text { Present } \\
\text { abcent }\end{array}$ & $\begin{array}{c}71 \\
462\end{array}$ & $\begin{array}{l}13.3 \\
86.7\end{array}$ \\
\hline $\begin{array}{l}\text { Ankiste fluid } \\
\text { Present } \\
\text { Abcent }\end{array}$ & $\begin{array}{c}13 \\
520\end{array}$ & $\begin{array}{c}2.4 \\
97.6\end{array}$ \\
\hline $\begin{array}{l}\text { Localization of fluid } \\
\text { Right } \\
\text { Left } \\
\text { Bilateral }\end{array}$ & $\begin{array}{c}302 \\
168 \\
60\end{array}$ & $\begin{array}{l}56.7 \\
31.5 \\
11.3\end{array}$ \\
\hline $\begin{array}{l}\text { Amount of fluid } \\
\text { Mild } \\
\text { Middle } \\
\text { Massive }\end{array}$ & $\begin{array}{l}126 \\
180 \\
219\end{array}$ & $\begin{array}{l}23.6 \\
33.8 \\
41.1\end{array}$ \\
\hline $\begin{array}{l}\text { Pleurodesis } \\
\text { Present } \\
\text { Abcent }\end{array}$ & $\begin{array}{l}255 \\
278\end{array}$ & $\begin{array}{l}47.8 \\
52.2\end{array}$ \\
\hline $\begin{array}{l}\text { Pleurodesis } \\
\text { Unsuccessful } \\
\text { Successful } \\
\text { Could not be assessed }\end{array}$ & $\begin{array}{c}45 \\
166 \\
42\end{array}$ & $\begin{array}{c}8.4 \\
31.1 \\
7.9\end{array}$ \\
\hline $\begin{array}{l}\text { Pleurodesis method } \\
\text { Closed underwater drainage } \\
\text { Pleural catheter } \\
\text { Other }\end{array}$ & $\begin{array}{c}247 \\
12 \\
3\end{array}$ & $\begin{array}{c}46.3 \\
2.3 \\
0.6\end{array}$ \\
\hline
\end{tabular}

\section{DISCUSSION}

The most common reasons for MPEs were reported to be lung cancer $(73 \%)$, breast cancer $(8.3 \%)$ and mesothelioma $(7 \%)$ in the present patient population. Pleurodesis was successful in ca. $31.1 \%$ of patients, who were offered chemical pleurodesis, and who were followed-up for at least 3 months.

Koegelenberg and et al found that the most common underlying diagnoses are lung cancer $(n=174,63.5 \%)$, breast cancer $(n=32,11.7 \%$, malignant mesothelioma $(n=27,9.9 \%)$ and unknown primary $(n=22,11.7 \%)(4)$. Lung cancer is the most frequent reason for MPEs, and accounts for nearly half of all cases (5).

Cytology is an initial test that has a mean sensitivity of $60 \%$; however, this depends on underlying primary tumours, preparation of samples, and experience of cytologist (6). Pleural fluid cytology's diagnostic yield regarding mesothelioma was reported lower, and many guidelines suggest the use of pleural biopsy as a preferred diagnostic method over fluid cytology, 
Table 3. The relationship between radiology, etiology and pleurodesis method according to the amount of pleural fluid

\begin{tabular}{|c|c|c|c|c|}
\hline & \multicolumn{3}{|c|}{ Amount of pleural fluid } & \multirow[t]{2}{*}{$\mathrm{p}$} \\
\hline & Mild & moderate & massive & \\
\hline $\begin{array}{l}\text { Diagnostic Method } \\
\text { Cytology } \\
\text { Surgical }\end{array}$ & $\begin{array}{l}118 \\
7\end{array}$ & $\begin{array}{l}172 \\
6\end{array}$ & $\begin{array}{l}206 \\
12\end{array}$ & 0,547 \\
\hline $\begin{array}{l}\text { Pleural thickening } \\
\text { Abcent } \\
\text { Present }\end{array}$ & $\begin{array}{l}95 \\
31\end{array}$ & $\begin{array}{l}135 \\
45\end{array}$ & $\begin{array}{l}155 \\
64\end{array}$ & 0,532 \\
\hline $\begin{array}{l}\text { Nodulation } \\
\text { Abcent } \\
\text { Present }\end{array}$ & $\begin{array}{l}107 \\
19\end{array}$ & $\begin{array}{l}160 \\
20\end{array}$ & $\begin{array}{l}187 \\
32\end{array}$ & 0,502 \\
\hline $\begin{array}{c}\text { Ankiste fluid } \\
\text { Abcent } \\
\text { Present }\end{array}$ & $\begin{array}{l}122 \\
4\end{array}$ & $\begin{array}{l}174 \\
6\end{array}$ & $\begin{array}{l}216 \\
3\end{array}$ & 0,384 \\
\hline $\begin{array}{l}\text { Localization of pleural fluid } \\
\text { Right } \\
\text { Left } \\
\text { Bilateral }\end{array}$ & $\begin{array}{l}76 \\
36 \\
13\end{array}$ & $\begin{array}{l}109 \\
46 \\
25\end{array}$ & $\begin{array}{l}114 \\
83 \\
21\end{array}$ & 0,076 \\
\hline $\begin{array}{l}\text { Et1ology } \\
\text { Pulmonary } \\
\text { Extrapulmonary } \\
\text { Mesothelioma }\end{array}$ & $\begin{array}{l}95 \\
20 \\
11\end{array}$ & $\begin{array}{l}125 \\
46 \\
9\end{array}$ & $\begin{array}{l}161 \\
42 \\
16\end{array}$ & 0,218 \\
\hline $\begin{array}{l}\text { Pleurodosis method } \\
\text { Closed underwater drai- } \\
\text { nage } \\
\text { Pleural catheter } \\
\text { Other }\end{array}$ & $\begin{array}{l}33 \\
1 \\
1\end{array}$ & $\begin{array}{l}79 \\
4 \\
0\end{array}$ & $\begin{array}{l}132 \\
7 \\
2\end{array}$ & 0,698 \\
\hline $\begin{array}{l}\text { Pleurodosis } \\
\text { Unsuccessful } \\
\text { Successful }\end{array}$ & $\begin{array}{l}5 \\
22\end{array}$ & $\begin{array}{l}16 \\
48\end{array}$ & $\begin{array}{l}23 \\
95\end{array}$ & 0,531 \\
\hline $\begin{array}{l}\text { Exitus } \\
\text { Alive }\end{array}$ & $\begin{array}{l}85 \\
41\end{array}$ & $\begin{array}{l}132 \\
48\end{array}$ & $\begin{array}{l}148 \\
71\end{array}$ & 0,391 \\
\hline
\end{tabular}

Table 4. Multivariete regression analysis for overall survival

\begin{tabular}{lcccc}
\hline & P & HR & \% 95 CI \\
\hline & & & Min & Max \\
Nodulation & 0,720 & 0,92 & 0.59 & 1.43 \\
Ankiste pleural fluid & 0,306 & 0.67 & 0.31 & 1.43 \\
Localization of pleural fluid & 0,392 & 1.10 & 0.87 & 1.39 \\
Etiology of pleural fluid & 0,094 & 0.79 & 0.60 & 1.04 \\
Amount of pleural fluid & 0,763 & 0.96 & 0.79 & 1.18 \\
Pleurodesis success rate & 0,005 & 1.79 & 1.19 & 2.69 \\
\hline
\end{tabular}

although fluid cytology is adequate in several experienced laboratories (7-10). Also, cytology may not be sufficient in some cases due to the need for tissue for targeted therapy (11). In our study, most patients were diagnosed with cytology. The majority of patients diagnosed with VATS were patients with mesothelioma.

Imaging techniques have significant roles in the diagnosis of patients who have suspected MPEs. Recently, thoracic ultrasound (TUS) is used routinely by respiratory physicians to guide pleural interventions for minimizing complications (12). National and international guidelines strongly recommend the technique (13). Evidence indicates that TUS might procure important data on the diagnostic pathway of pleural effusion. In TUS, pleural/diaphragmatic thickening and nodularity are highly specific in terms of malignancy and might assist to expedite timely investigation in patients who have high risks (14). In our study, we only used ultrasound for location marking during thoracentesis. 
In our present day, contrast-enhanced thoracic computed tomography is the gold standard imaging modality in this respect, and might also procure useful data on the pleural cavity as a whole and the primary tumor site and stage. In our study, the most common radiological feature in computed tomography was pleural thickening and nodulation. The group in which the amount of pleural fluid was monitored massively was lung carcinoma and was mostly in the adenocarcinoma group. In the extrapulmonary group, massive effusion was seen more in breast cancer, while the amount of fluid was less in mesothelioma. Another study found that the amount of fluid in mesothelioma was higher. Also in the same study, the size was nearly equally spread from small to large in lung cancer (4). No relationship was found between the amount of pleural fluid and cell type, survival, pulmonary, extrapulmonary malignancy and mesothelioma, in our study.

The treatment options for MPE are therapeutic thoracentesis, Indwelling pleural catheters (IPCs) and pleurodesis. Therapeutic thoracentesis can be repeated (as an outpatient), particularly for patients who have slow recurrence rates, in those with very short anticipated survival or poor performance (1). It was reported in a recently published retrospective cohort study that guidelines using definitive procedures (IPC or pleurodesis) compared with repeated thoracentesis were correlated with fewer subsequent procedures and complications, but pleurodesis resulted in more inpatient days (15). Chemical pleurodesis, which is achieved by the installation of a sclerosant via an intercostal drain (ICD) is still favored as the first-line intervention in patients who have anticipated survival of $>3$ months (16). Chemical pleurodesis (achieved via intercostal drain or pleuroscopy) and IPC show equal effects on patient-based results, despite the fact that patients treated with IPC spend less time in hospital and less requirement for repeated pleural drainage intervention (17). The most common method used in our study was tube thoracostomy. Pleurodesis was found to be successful in $31.1 \%$ of the patients. In a study, it was seen that the rate of patients offered pleurodesis (41.8\%) and 3-month radiological treatment had a success rate of $88.0 \%$, which is higher than our success rate, and success rates generally ranged between $30 \%$ and $50 \%$ and $75 \%$ and $90 \%$, respectively (18).

The median survival is between 3 and 12 months; however, it might also vary at significant levels according to cell types, performance status, staging, and whether a chemosensitive malignancy is detected (19). In our study, if pleurodesis was successful, it was found that patients lived longer. The survival of patients with mesothelioma was significantly longer than those of the lungs and extrapulmonary ones. It was observed that the extrapulmonary ones lived significantly longer than those with lung cancer.

One of the strengths of our study is that the number of patients is sufficient. However, the number of mesothelioma patients being less than lung cancer patients may be a limitation. One of the limitations of our study is that pleural fluid biochemical parameters that affect the success of pleurodesis are not included in the study. Another limitation is that apart from the type of tumor affecting prognosis, the patient's performance is also not recorded due to the retrospective study. A limitation of the study was the retrospective design and likely selection bias because patients who had advanced malignancy might have been referred directly for palliative care, without further investigation.

In conclusion, the main reason for MPEs was lung cancer, followed by breast cancer and mesothelioma in the present study. It was seen that the amount of pleural fluid did not have any clues regarding etiology. In this population, chemical pleurodesis was a viable palliative measure for MPE. It was also observed that successful pleurodesis had a significant contribution to survival.

Ethics Committee Approval: Ethical approval was obtained from Local Ethics Committee of Dr. Suat Seren Chest Diseases and Surgery Training and Research Hospital with the number 49109414-604.02 dated 22.04.2019.

Conflict of Interest: There is no conflict of interest.

Funding: There is no financial support.

Informed Consent: This a retrospective study.

\section{REFERENCES}

1. Azzopardi M, Porcel MJM, Koegelenberg CFN, Lee YCG, Fysh ETH. Current controversies in the management of malignant pleural effusions. Semin Respir Crit Care Med 2014;35(6):723-31. https://doi.org/10.1055/s-0034-1395795

2. Fitzgerald DB, Koegelenberg CFN, Yasufuku K, Lee YCG. Surgical and non-surgical management of malignant pleural effusions. Expert Rev Respir Med. 2018;12(1):15-26. https://doi.org/10.1080/17476348.2018.1398085

3. Antony VB, Loddenkemper R,Astoul P, Boutin C, Goldstraw $\mathrm{P}$, Hott J, et al. Management of malignant pleural effusions. Eur Respir J 2001;18(2):402-19. https://doi.org/10.1183/09031936.01.00225601

4. C F N Koegelenberg, S M Bennji, E Boer, P T Schubert, J A Shaw, B W Allwood, et al. The current aetiology of malignant pleural effusion in the Western Cape Province, South Africa S Afr Med J 2018;108(4):275-7. https://doi.org/10.7196/SAMJ.2018.v108i4.12936

5. Hsu C. Cytologic detection of malignancy pleural effusion: a review of 5,255 samples from 3,811 patients. Diagn Cytopathol 1987; 3: 8-12. https://doi.org/10.1002/dc.2840030103

6. Hooper C, Lee YC, Maskell N, BTS Pleural Guideline Group. Investigation of a unilateral pleural effusion in adults: British Thoracic Society Pleural Disease Guideline 2010. Thorax 2010; 65(2): ii4-17. https://doi.org/10.1136/thx.2010.136978

7. A A Renshaw, B R Dean, K H Antman, D J Sugarbaker, E $\mathrm{S}$ Cibas. The role of cytologic evaluation of pleural fluid in the diagnosis of malignant mesothelioma. Chest 1997; 111: 
106-9.

https://doi.org/10.1378/chest.111.1.106

8. van Zandwijk N, Clarke C, Henderson D, Musk AW, Fong $\mathrm{K}$, Nowak A,et al. Guidelines for the diagnosis and treatment of malignant pleural mesothelioma. J Thorac Dis 2013; 5: E254-307. doi: 10.3978/j.issn.2072-1439.2013.11.28. PMID: 24416529; PMCID: PMC3886874.

9. Scherpereel A, Astoul P, Baas P, Berghmans T, Clayson H, de Vuyst P, et al. Guidelines of the European Respiratory Society and the European Society of Thoracic Surgeons for the management of malignant pleural mesothelioma. Eur Respir J 2010; 35: 479-95. https://doi.org/10.1183/09031936.00063109

10. Segal A, Sterrett GF, Frost FA, Shilkin KB, Olsen NJ, Musk $\mathrm{AW}$, et al. A diagnosis of malignant pleural mesothelioma can be made by effusion cytology: results of a 20 year audit. Pathology 2013; 45: 44-8. https://doi.org/10.1097/PAT.0b013e32835bc848

11. Henderson DW, Reid G, Kao SC, van Zandwijk N, Klebe S. Challenges and controversies in the diagnosis of mesothelioma: Part 1. Cytology-only diagnosis, biopsies, immunohistochemistry, discrimination between mesothelioma and reactive mesothelial hyperplasia, and biomarkers. J Clin Pathol. 2013 Oct;66(10):847-53. doi: 10.1136/jclinpath-2012-201303. Epub 2013 Jun 27. PMID: 23814259 .

https://doi.org/10.1136/jclinpath-2012-201303

12. Gordon CE, Feller-Kopman D, Balk EM, Smetana GW. Pneumothorax following thoracentesis: a systematic review and meta-analysis. Arch Intern Med 2010; 170: 332-9. https://doi.org/10.1001/archinternmed.2009.548

13. Havelock T, Teoh R, Laws D, Gleeson F; BTS Pleural Disease Guideline Group. Pleural procedures and thoracic ultrasound: British Thoracic Society Pleural Disease Guideline 2010. Thorax 2010; 65(2): ii61-76. https://doi.org/10.1136/thx.2010.137026

14. Bugalho A, Ferreira D, Dias SS, Schuhmann M, Branco JC, Marques Gomes MJ. The diagnostic value of transthoracic ultrasonographic features in predicting malignancy in undiagnosed pleural effusions: a prospective observational study. Respiration 2014; 87: 270-8. https://doi.org/10.1159/000357266

15. Ost DE, Niu J, Zhao H, Grosu HB, Giordano SH. Quality gaps and comparative effectiveness of management Strategies for recurrent malignant pleural effusions. Chest 2018; 153: 438-52. https://doi.org/10.1016/j.chest.2017.08.026

16. Roberts ME, Neville E, Berrisford RG, Antunes G, Ali NJ, BTS Pleural Disease Guideline Group. . Management of a malignant pleural effusion: British Thoracic Society Pleural Disease Guideline 2010. Thorax 2010; 65( 2): ii32-40. https://doi.org/10.1136/thx.2010.136994

17. Koegelenberg CFN , Jane A. Shaw, Elvis M. Irusen and Y. C. Gary Lee. Contemporary best practice in the management of malignant pleural effusion. Ther Adv Respir Disn 2018; 12: $1-13$. https://doi.org/10.1177/1753466618785098

18. Dresler CM, Olak J, Herndon JE 2nd, Richards WG, Scalzetti E, Fleishman SB, et al. Phase III intergroup study of talc poudrage vs talc slurry sclerosis for malignant pleural effusion. Chest 2005;127(3):909-15. https://doi.org/10.1378/chest.127.3.909

19. Pilling JE, Dusmet ME, Ladas G, Goldstraw P. Prognostic factors for survival after surgical palliation of malignant pleural effusion. J Thorac Oncol 2010; 5: 1544-50. https://doi.org/10.1097/JTO.0b013e3181e95cb8 